Ground-water hydrology, Probability and statistics, Systems approach to water management Part I: Introduction, Water quality, treatment, and supply, Introduction to computer science and the use of hydrological databases, Introduction to computer programming, and Hydrological data analysis.

- Field training (30 hrs).

\section{Second Year}

This leads to a Master's degree in Hydrology for successful candidates, and includes:

- Optional courses (minimum $190 \mathrm{hrs}$ )

Orientation A: Surface-water hydrology:

Synoptic meteorology, Advanced hydraulics, Advanced surface-water hydrology, and Watershed management.

Orientation B: Ground-water Hydrology:

Flow through porous media, Advanced geohydrology, Hydrogeology and geophysical prospection, and Applied mathematical methods.

Orientation C: Water Pollution Control:

Water chemistry and water quality, Water-quality models, Hydraulics of wastewater collection and water supply, and Wastewater purification and water treatment.

Common to All Orientations:

Systems approach to water management Part II: Basic concepts, Statistical applications in hydrology, Teledetection techniques, Dam-sites and drilling techniques, and Time series analysis.

- Seminars (30 hrs)

- Field training (90 hrs)

- M.Sc. thesis

\section{Fellowships are Available in Five Frameworks}

1) Bilateral agreements with Belgium; applications must be introduced by national authorities at Belgian Embassies.
2) Multilateral programmes through United Nations Agencies; applicants must be introduced through the intermediate action of the UN regional representatives or the UN Department of Technical Cooperation for Development.

3) Exchange programmes as part of the International Cultural Agreements of several nations with Belgium; applications should be made through the appropriate authorities at a Belgian Embassy.

4) The European Development Fund for candidates from countries participating in the Convention of Lomé; applicants should contact the European Community (EC)-Delegation in their home country.

5) Programmes of international organizations (e.g. UNESCO-Participation Programme, WMO, WHO, FAO, etc.); applicants should contact the local representative in their home country.

The programme is located in Brussels at the Faculty of Applied Science, Free University of Brussels (VUB), and is also supported by the Universities of Antwerp, Ghent, and Louvain. Courses start on September 1st of each year, with English the medium of instruction. Students who have a Bachelor's degree (B.Sc. or B.Eng.) or its equivalent ( $\mathrm{Li}$ cence) will be considered for admission, female candidates being given special consideration as recommended by UNESCO. Students should have an excellent background in mathematics. Applications should normally be sent on the appropriate forms not later than February 1st of each year. Further information, including a brochure with application form, can be obtained from the undersigned:

A. VAN DER BEKEN, Professor Dr ir
Director of the Programme
Laboratory of Hydrology
Vrije Universiteit Brussel
Pleinlaan 2
B-1050 Brussels
Belgium.

\title{
Major Corporations to Train Indonesian Officials in Industrial Environmental Management
}

In a Pilot Fellowship programme to focus on environmental impact assessment, industrial audit procedures, and hazardous waste management, the Dow Chemical Company, Exxon, and Mobil Corporation, will train Indonesian government officials in industrial environmental management techniques. The new Fellowship programme is being established by the World Environment Center, a not-for-profit non-advocacy organization.

In its pilot phase, Indonesia Technical Assistance Project (ITAP) will provide the opportunities for three mid- and senior-level officials to spend up to three months with participating American companies. Each Fellow will receive individualized training, with emphasis on the abovementioned three important aspects of environmental concern.

The programme was established by the World Environment Center (WEC) at the request of Indonesia's Minister of Population and Environment, Dr Emil Salim. Direct costs covering US travel and living expenses will be contributed by participating companies, and international travel will be paid by Indonesia.

The Indonesian Technical Assistance Project is unusual in that, though governmentally-oriented, it is funded en- tirely by industry. Recent events having underscored the need for world-wide environmental management systems, this programme is a good example of how a partnership of government and industry can further such a goal.

Indonesia's Ambassador Soesilo Soedarman has commented that 'Indonesia welcomes this project as an example of cooperation with the United States' private sector in addressing an increasingly important issue: how to prevent effectively some of the potentially negative effects of industrialization.'

ITAP is an outgrowth of the Center's International Environment and Development Service (IEDS), which sends volunteers from 25 US companies to industrializing countries to perform environmental audits and provide training in industrial health and safety. The US $\$ 1.4$ million, fiveyears' programme (1983-88) is funded by the US Agency for International Development and US industry, and currently operates in the Near East and eastwards in Asia.

Among the companies that have participated in IEDS missions are Allied-Signal, Amax, Calgon, Combustion Engineering, Dow Chemical, Dundee Cement, Koppers, Pennzoil, Occidental Corporation, Tenneco, and US Steel. 
The World Environment Center was established in 1974. It provides information and technical assistance worldwide through conferences, meetings, publications, and the services of volunteers from US industry and also private citizens.
Whitman Bassow, President World Environment Center 605 Third Avenue, 17th Floor New York NY 10058, USA.

\section{Detergents in France, Italy, and West Germany}

A legislative decree laying down urgent measures to control water eutrophication has recently come into force in Italy. It bans the production, import, storage, and sale, of detergents exceeding specified levels of phosphorus (2 to $6 \%$ depending on the purpose of the detergent). (Decrettolegge No. 667.) (Italian National Agency.)

In France the Ministry of the Environment has just signed an agreement with detergent manufacturers. The composition of detergents must henceforth be detailed on the package, to reduce excess amounts of phosphates in the environment. (Ministère de l'Environnement, 14 Bd du Général Leclerc, F-92524 Neuilly-sur-Seine, Tel. 4758 12.)
The revision of the law on detergents in West Germany is primarily designed to improve environmental tolerance of detergents. However, it does not provide for acceptable general levels of particular components, nor will it reduce the use of detergents and other cleansing agents. (German National Agency.)

\section{COUNCIL OF EUROPE Centre Européen d'Information} pour la Conservation de la Nature BP 431 R6

F-67006 Strasbourg France.

\section{Alarming Depletion of Ozone Layer Above Antarctica: Scientists Seeking Cause}

Four teams of scientists will make a midwinter (in that continent) flight to Antarctica in August of this year to try to determine the cause of alarming annual deviations in the protective layer of ozone $\left(\mathrm{O}_{3}\right)$ above that continent. Ozone exists in very small amounts throughout the atmosphere but is concentrated principally in the 'ozone layer' or 'shield' situated about 15 miles $(24 \mathrm{~km})$ above the surface of the Earth. This shield of ozone is of critical importance to life on Earth, because it screens out almost all of the Sun's harmful ultraviolet radiation. Among other effects, scientists fear that a weakened ozone shield would increase the incidence of skin cancer and might seriously harm plant life.

World attention was focused on the problem in 1975 when it was suggested that the ozone layer might be affected by high-flying aircraft, agricultural fertilizers, and the use of 'freons' in aerosol sprays and refrigerators. More recently the ozone layer has startled the scientific world when a 50\% decrease has been observed in its abundance over Antarctica in the Antarctic spring-time-apparently very much greater than should be expected for the presentday atmosphere.

A scientific explanation for the annual ozone depletion phenomenon over Antarctica is vital to research workers, inter alia to correct computer models of the composition and dynamics of the stratosphere.

The four teams that are going to Antarctica include three scientists from the University of Wyoming, three from the State University of New York at Stony Brook (SUNY), four from the Jet Propulsion Laboratory (JPL) in Pasadena, California, and three from the National Oceanic and Atmospheric Administration. The ozone study, to be based in McMurdo Station-the principal US scientific outpost in Antarctica-is an interagency cooperative effort involving the National Science Foundation (NSF), the National Aeronautics and Space Administration (NASA), and the National Oceanic and Atmospheric Administration (NOAA). The Chemical Manufacturers' Association is supporting some of the research workers. The NSF provides operational support and manages all US activities in Antarctica.

The hazardous winter flight to McMurdo, called WINFLY, normally is restricted to moving scientists who are conducting experiments and personnel who are essential for the seasonal opening of that station on Ross Island. Because of the importance of the ozone study, one aircraft of the six that make the 2,100 -miles' $(3,360 \mathrm{~km})$ flight will be devoted to this National Ozone Expedition.

The Wyoming team will launch thirty 19,000-cubic-feet (ca $537 \mathrm{~m}^{3}$ ) balloons carrying ozone-measuring instruments and three 54,000-cubic-feet $\left(\mathrm{ca} 1,530 \mathrm{~m}^{3}\right)$ balloons carrying aerosol measuring devices. The SUNY team will use microwave measuring devices to determine molecular gases in the atmosphere. JPL scientists will measure absorption by atmospheric gases of solar infrared radiation. The NOAA team will measure the solar visible light that is scattered by other atmospheric constituents.

Recent studies have reported the large systematic changes in the ozone layer above Antarctica to be of 'unprecedented proportions'. The amount of ozone over Halley Bay, in the eastern portion of the Weddell Sea, has decreased every spring since 1975 , according to the British Antarctic Survey. The present ozone readings are about half the amount observed in the early 1970 s. Satellite data have shown that the spring ozone depletion is not confined to the Halley Bay region, but extends over most of Antarctica, creating a 'hole in the Ozone' about the size of the United States.

One puzzling aspect of the Antarctic ozone problem is that the dramatic deviations from expected amounts are believed to occur only in the local spring-from about midAugust to the end of October. The largest rate of ozone depletion occurs during September, suggesting that the ozone depletions may be linked to the return of sunlight to Antarctica, following the end of the 'polar night' period.

The 13 scientists who will concentrate on the ozone problem are among approximately 200 research workers and support personnel who will fly to McMurdo from Christchurch, New Zealand, to help prepare for the 198687 science season. They make the eight-hours' flight in ski-equipped C-130 aircraft owned by the NSF and flown by Navy pilots.

RaLPH KaZARIAN

National Science Foundation $1800 \mathrm{G}$ Street

Washington

DC 20550, USA. 